\title{
Language Contact, Evolution, and Death: How Ecology Rolls the Dice
}

\author{
Salikoko S. Mufwene
}

\section{Introduction}

This paper is about what can be characterized, borrowing a term from population genetics, as language evolution. I mean by this phrase no more than the long-term change that a language qua species undergoes in isolation or under contact conditions. The change may amount to different ways of expressing things (phonologically, morphosyntactically, lexically, or pragmatically), more, or less, complexity (in any structural or pragmatic respect), diversification into other varieties (regardless of whether these are identified as dialects or separate languages), to erosion of the vitality and/or structures of a language variety (also known as attrition), or its death. Not all language varieties have had a life marked by all such changes, nor have they all followed identical evolutionary paths if they underwent combinations of such changes. To account for both differences and similarities in these diverse evolutions, it will be necessary to 
understand, as in population genetics, the respective ecologies of the developments. ${ }^{1}$

Johanna Nichols (1994:276-77) distinguishes between different senses of evolution, including "progressive change toward increasing complexity" and "Darwinian evolution, that is, change brought about by natural selection of existing variation." I assume in this essay that evolution has no purpose or defined goals; it should not be interpreted as progress (Gould 1993:323), although it is often characterized in terms of adaptations to changing ecology, which actually explains why at least some evolutionary paths are reversible (as acknowledged by Nichols). Linguistic systems may evolve as much toward more structural complexity as toward more simplicity, just as they may be restructured (i.e., reorganized, Mufwene 1996a) without becoming more complex or simpler. Unlike Johanna Nichols, I show that natural selection (out of competing alternatives) plays an important role in language evolution, a natural consequence of analogizing language with population (Nichols 1994:12) at the mercy of ecology. The latter may sustain variation, but sometimes it favors some variants over others, often also prompting the advantageous ones to adapt.

\section{Language as species}

Since the nineteenth century, language has been claimed to have life. It has also been analogized with organism in biology. While the species metaphor will underlie much of the following discussion, I reject the organism alternative as inaccurate, for a number of reasons.

First of all, the language-as-organism metaphor does capture variation within language, thus making it more difficult to think of language internal variation as what makes internally motivated change possible. ${ }^{2}$

Second, the analogy makes it also difficult to account for partial or differential change in a language where some speakers may participate in the change whereas others may not or do so in a different way. This phenomenon can be illustrated by, for instance, the fact that English has undergone divergent kinds of changes in England and in North America since the seventeenth century and is spoken differently in the two

II do not want to suggest that language evolution is in all, or most, respects like species evolution (see below). There are, however, some similarities between the concepts of language and species, which I find informative and would like to use cautiously to shed light on the process of language evolution.

${ }^{2}$ As much as genetic linguistics has been influenced by biological taxonomies (Mufwene 1998), it is curious that language-internal variation has not been made as critical to theories of language change as species-internal variation to evolutionary theories. Much of the substance of the latter presupposes variation. 
polities. ${ }^{3}$ A notion of organism that accounts for such a differential evolution would be tantamount to that of population.

Third, the metaphor cannot account for variable speeds in the way long-term change takes place in a language, proceeding not only faster among some speakers than among others (hence differentially in a communal system), but also faster in some dialects than in others. This may be illustrated with statistical variation in the usage of aller in French and (be) going to $>$ (be $\left.e_{\text {contracted }}\right)$ gon(na) in English as future auxiliary verbs. ${ }^{4}$ A notion of organism that captures such facts would not in essence be different from that of population.

Fourth, the same language may thrive in one territory and yet fall into attrition or die in another (Hoeningswald 1989). This was the case of several immigrant languages in the New World which continue to be spoken in their homelands. Only a notion of organism which is tantamount to that of population can capture such differential processes in the life of a language.

Fifth, as Jerry Sadock (personal communication, May 1998) observed, language and dialect boundaries are fuzzy; there is no question of fuzziness in the boundaries of organisms as individuals. The closest analog to an organism may be an idiolect. Just as one needs more than one organism to speak of a population qua species, a language is a projection over idiolects which are governed by similar structural and pragmatic principles or which may be traced to the same ancestor. ${ }^{5}$

${ }^{3}$ The phenomenon has been characterized as speciation in evolutionary theories. It occurs when a species splits into two or more kinds under conditions of separation in which its members develop different self-reproducing patterns or behavioral characteristics. This often happens when such subgroups evolve in separate geographical locations, at the mercy of different ecological factors. Geographic specialization is another term used to describe such adaptations (Thompson 1994).

${ }^{4}$ There are also cases where, regardless of whether it is truly a change, a phenomenon is contained within one particular segment of the population, without affecting (seriously) other members of the community. Such appears to be the case with usage of like as a discourse marker to introduce what may be interpreted as a quotation (albeit an unfaithful one) but especially to signal change of speakers or points of view in a narrative. It seems to be associated with a particular generation (the young) and speakers outgrow it, consistent with age-grading. The language qua organism metaphor fails to capture this, especially because speakers do not graduate from age-groups all at the same time nor at the same rate. Members of a community are not all born the same day, month, or year. The life of a community depends on an uneven and quite variable staggering of several individual lives.

5O'Hara (1994) provides an informative discussion of the different ways species has been defined in biology. 
I thus break with the tradition, as in Mufwene (1996a), and I submit that species, not organism, is a more adequate analog for language. ${ }^{6}$ Consistent with Hagège (1993), with Keller (1994), and with practitioners of accommodation theory (e.g., Giles and Smith 1979) and of network theory (James Milroy 1992, Milroy and Milroy 1985), I also submit that the agents of language are individual speakers. The variation that matters to evolution starts really at that inter-idiolectal level, before reaching the next higher level of cross-dialect and/or cross-language differences. As in population genetics, changes start taking place by selection at the level of individuals who, while interacting with each other, cause their varying features to compete with each other. That is, when individual speakers communicate with and accommodate each other, some alternatives among the competing structural options may be selected out of a dialect or a language, or at least their significance may be decreased. If Labov (1998) is correct in observing that there is not as much inter-idiolectal variation as I suggest is possible, this state of affairs would be the result of the kinds and extents of accommodations that speakers make to each other in particular communicative networks or speech communities, as discussed below. However, those of us teaching syntax classes have witnessed several instances where one construction is (un)acceptable to some native speakers but not to others, e.g., Larry may be sick and Bill may too.

One important caveat is in order here regarding how fast changes spread in a speech community: typically faster than in a species in which change is effected through vertical transmission of genes from one generation to another. However, linguistic features are transmitted primarily horizontally (Mufwene 1997a), more or less on the pattern of features of parasites, through speakers' interactions with members of the same communicative network or of the same speech community. This peculiarity makes it possible for a new feature to spread fairly rapidly. If such a feature leads to some restructuring qua system reorganization, such as the vowel shifts in North American white varieties of English (Labov 1994, Bailey and Thomas 1998), the process need not wait for generations to

${ }^{6}$ The reason why, unlike in Mufwene (1996a), I will capitalize here on the notion/term species rather than population is that no justification need be provided for lumping several individuals together as a population. One is needed for grouping them as a species, for example, if the individuals descend from the same ancestor and/or share genes. Such is also the case for people who are said to speak the same language. They need not understand each other, as long as one may show some genetic and/or structural connection among their idiolects or dialects. Things are more complicated with language, since native speakers may claim or deny such a connection on ideological grounds, such as in the Balkans, where language boundaries have often been redefined (Friedman 1996). For the purposes of academic classifications, however, the above explanation stands. 
become evident, although there is generational variation in the way it takes place in different idiolects. ${ }^{7}$

Like species, language is an aggregating construct, a projection over individual idiolects assumed to share common ancestry and several structural features through the interaction of their speakers with each other. Membership in a species is predicated on a family resemblance model, though there is a range within which variation is considered normal and outside which one is considered not speaking a particular language natively or fluently. From this perspective, evolution consists of changes within the structure of the acceptable range of variation within a species.

A central question in the approach outlined here is why language boundaries are not more random and why there is not more variation among speakers of the same language. The answer to this question lies in the notion of contact, which in linguistics has typically been considered at the level of languages or dialects. Weinreich (1953) states it correctly: contact takes place within the multilingual or multidialectal individual. Unfortunately, most of the literature on language contact, other than code switching and second-language acquisition/learning, has ignored individuals and focused on populations, making it more and more difficult to understand such matters as borrowing into, and substrate influence on, a particular language.

I submit that there is one basic form of contact, that between idiolects of individuals who interact and communicate with each other. This is a basic factor that accounts for what Le Page and Tabouret-Keller (1985) identify as focusing, a process whereby members of the same speech community communicate more like each other than like nonmembers. Through the accommodation process discussed above and below, some features gain selective advantage over other competitors which are selected out. ${ }^{8}$ In some cases, a network starts using a feature which is more typical of a different network even when most of the members of the two networks do not interact with each other. Individuals commuting between such networks are the agents of transmission (Milroy and Milroy

${ }^{7}$ Consistent with variation theory in linguistics, one may assume such variability in a speech community to be the counterpart of the distribution of advantageous and disadvantageous genes among the members of a changing species. The only difference is that in a species where the selective advantage of some genes depends primarily on their vertical transmission, it takes many generations before the disadvantageous genes become latent and the change at the level of the species conspicuous.

8 There are, of course, several situations in which no particular competing feature prevails over others, such as when more than one pronunciation is accepted for the same word, e.g., [dayrekt] versus [dIrعkt] for direct, or when more than one strategy can be used for the same function, e.g., the person to whom you spoke versus the person who you spoke to versus the person (that) you spoke to. 
1985), hence, initial agents of the change as they transport linguistic features, like they would germs, from one community to another.

Nothing by way of focusing or change would take place without individuals who interact with each other, setting their respective features in competition with each other, and having to accommodate each other by dropping some features, or accepting some new ones, or even by modifying their respective individual systems. Little by little, thanks more to lateral than to vertical transmission, linguistic features spread in a community and affect a whole language, often leading to a minor or serious reorganization of its system. Speciation into separate subspecies (identified as dialects or separate languages, depending on the speakers' ideological inclinations) obtains when networks of communication have little contact with each other and make different selections even out of the same pools of features. ${ }^{9}$

Although I oversimplify things here, the above discussion accounts, at least partially, for differences that have developed, for instance, between British, American, and Australian Englishes, or between White and AfricanAmerican nonstandard varieties of English. A similar explanation applies to the development of different regional and social dialects, based on which individuals interact with which other individuals the most, what features have competed with each other within their networks of communication, and which particular selections speakers have made to accommodate each other, thereby "focusing" their varieties in diverging directions.

Note that language is more of the parasitic, more specifically symbiotic, than of the autonomous kind of species. Parasitic populations are apparently a fairly adequate analog chiefly because a language does not exist without speakers, just like parasites do not exist without hosts. The life of a language is, to borrow from Brown, "closely tied to the distribution of [its] hosts, which provide many of the essential environmental conditions necessary to [its] survival and reproduction" (1995:191). Many of the ecological factors that affect a language are not necessarily physical features of its speakers but features of other parasitic systems that are hosted by the same individuals, such as culture (which brings along notions such as status, gender, and power) and other language varieties. ${ }^{10}$

${ }^{9}$ In some cases, it is not so clear-cut that different features have been selected into, or out of, the linguistic system. Differences between two varieties may lie in the weights accorded to the competing variants and/or to their conditioning factors, the kinds of things that have concerned quantitative sociolinguists over the distinctiveness of African-American vernacular English compared to other nonstandard varieties of English.

${ }^{10}$ Among other justifications for comparing language to parasitic/symbiotic species are the following: (1) a language vanishes if the population of its speakers is decimated; (2) a language falls into attrition and/or dies if things are done to its hosts which do not enable it to thrive, for instance, if its speakers are relocated to an environment where another 
By the same token, knowledge of more than one language by the same speaker makes one linguistic system part of the ecology for the other, just as much as knowledge of competing structural features of the same language used by other speakers makes them part of the ecology for the speaker's own features. (The competing features may be phonological, morphological, syntactic, semantic, or pragmatic.) One speaker's features may affect another speaker's way of speaking, thereby setting conditions for long-term change in the overall structure of a language qua species. All this leads to two important questions regarding language evolution: (1) How can feature competition be articulated in an approach in which one feature becomes part of the ecology for another, assuming ecology to be both external and internal to the species? (2) How different is internally motivated change from externally motivated change? It will help to explain more explicitly what ecology stands for.

\section{The ecology of language}

Ecology has been invoked to account for language evolution for quite some time now, although less frequently than might be expected, despite progress in the ethnography of communication. Among the earliest instances are the Voegelins and Schutz (1967) and Haugen (1971), who use it basically in the sense of the social environment in which a language is spoken, for instance, in reference to whether socioeconomic conditions in a particular polity favor or disfavor usage of a particular language. This is also the sense in which Mühläusler (1996) uses it, as he puts the coexistence of Melanesian languages among themselves and with the invading European languages in perspective. ${ }^{11}$ Like them, I am interested in how

language must be spoken as a vernacular; (3) whether or not a language thrives or falls into attrition depends very much on social habits of its speakers, e.g., whether, in a multilingual community, knowledge of a particular language provides some socioeconomic advantages or disadvantages (in ways similar to avoiding hosts of a particular parasite or to selecting individuals more resistant to it in interbreeding patterns); (4) parasites affect the behaviors of their hosts and adapt themselves to the hosts' behavioral responses (Thompson 1994:123); (5) different life histories of both parasites and hosts favor different patterns of specialization geographically and otherwise; and (6) parasitic populations are more likely to specialize, hence to diversify into related subspecies, than their hosts (Thompson 1994:132), as well illustrated by dialectal speciation. In the latter case, the development of separate dialects is not necessarily correlated to the development of different ethnic or biological groups.

11 See also Robinson (1997). Dixon (1997) and Mazrui and Mazrui (1998) may be interpreted in this light, too, although they hardly use the term ecology. Manheim (1991:31) invokes ecology, also, characterizing it as "the ways in which linguistic differences are organized and set into a social landscape," including, among other things, "the ways in 
the ethnographic environment affects language, in this particular case, how it may trigger or influence the restructuring of a language. However, I am also influenced by how the term is used in macroecology, a branch of population genetics in which ecology is treated as a cover term for diverse factors which are both external and internal to a species and bear on its evolution, for instance, "population size, habitat requirements, and genetic variation" (Brown 1995:5), as well as "differences in initial conditions, stochastic events, time lags, processes operating on different time scales, and spatial subdivisions" (Brown 1995:15-16). ${ }^{12}$

A practical way to approach this subject matter without making it too abstract is by discussing specific cases and showing how they justify invoking ecology to explain language evolution. I will select them from the experience of colonization and the fates of various languages in North America. I will often go beyond these geographical and linguistic delineations to compare language evolution in North America with changes elsewhere. I use colonization to characterize any case where a population migrates on its free will from a territory and settles in another in which it controls much of its fate. This justifies my observations on the earliest stages of the development of the English language from settlements of the Angles, the Jutes, and the Saxons in England. As I discuss colonial phenomena, I also cover all sorts of structural and ethnographic developments in a colonized territory which affect languages that are indigenous to it or were brought to it by third-party populations.

A species-external interpretation of ecology: An ethnographic perspective. The language contact literature of the New World has focused mostly on what European colonial languages have become, especially on the varieties spoken by descendants of non-Europeans and the extent to which they have been influenced by African languages. More has been written on the survival of African cultures than on the survival of African languages. Warner-Lewis's (1996) discussion of Trinidadian Yoruba is a rare case, compared to the vast literature on Haitian Voodoo, on Shango cults in several parts of the New World, and on Brazilian Orisa rites. To be sure, there have been some publications on African-based secret languages but not on the survival of African languages as vernaculars.

which language and dialect differences are institutionally channeled and used." I focus in this essay mostly on the variation aspect of ecology, which bears directly on competition and selection.

${ }^{12}$ Space constraints prevent me from discussing all these factors, some of which are dealt with in Mufwene (1996a) and in much of the literature on the development of creoles. I focus here on a subset that bears on the few language evolution topics that I discuss. 
Warner-Lewis (1996) is exceptional because survivals of such vernaculars are also rare.

The American colonial socioeconomic settings were not hospitable ecologies to the survival of African languages, in part because the plantation populations were ethnolinguistically so mixed that a lot of Africans could not speak their native vernaculars with anybody else and knowledge of these must have fallen into attrition, an experience common among some Africans living in North America today. Even on plantations where a few Africans shared an African language, be it a vernacular or a lingua franca, this had to compete on every plantation or polity with the local European-lexicon vernacular. Typically, this colonial variety gained selective advantage from being associated with the dominant political and/or socioeconomic group, which everybody had to accommodate. It prevailed not only over African languages but also over other languages brought by Europeans of various nationalities.

Species and ecology become useful metaphors here in several ways. One of them is that only the parts of those languages which came to the New World were negatively affected by the competition with the local vernaculars. They died in the relevant colonies but not in their homelands. The case of European languages is doubly interesting, because they died in some colonies but not in others. For instance, French died in Maine but not in Quebec, and it has been belatedly endangered in Louisiana. Dutch survived in a new, colonial, but not extensively restructured form in the New Netherland (New Jersey and New York), identified as Negerhollands in the Virgin Islands and as Berbice Dutch in Guyana, but it apparently thrived (identified also as Dutch) in Suriname, where it was spoken by the Dutch rulers and the non-Dutch elite as the official language but not as a vernacular. ${ }^{13}$

These examples also illustrate how selection operates on and through individuals. The loss of both African and European languages did not take place concurrently in all its speakers. The fact that some African languages survived as ritual or secret languages in some communities likewise suggests that for a while these languages were also transmitted from one generation to another. However, in population genetics terms, there were fewer and fewer individuals who could successfully contribute as

${ }^{13}$ I discuss survival in, and development of, new forms for European languages below. The last speaker of Negerhollands, literally 'Negro Dutch', died a little over a decade ago (Smith 1995), and fluent speakers of Berbice Dutch must be dead or dying by now, based on Kouwenberg (1994). The vernaculars spoken by Surinamese of African descent are creoles lexified mostly by English, e.g., Sranan (also influenced by Dutch), and at least one of them, Saramaccan, partly also lexified by Portuguese. 
agents or as hosts to the reproduction of the relevant species, and little by little the relevant languages died in the relevant territories.

Yoruba in Trinidad and French in Louisiana highlight an important aspect of the ecology of language which determines whether or not a language may thrive in a new setting. The Yoruba which survived in Trinidad up to the mid-twentieth century came over with post-Abolition indentured servants, virtually all who originated in the same part of Nigeria and lived in communities marginalized from the creole ones. Its death was an inverse reflection of its relative integration in the larger, creole community. In the case of French in the United States, the Louisiana Purchase in 1803 was resented by the French colonists, and the integration of the francophone and anglophone populations of European descent has been a gradual process. The endangerment of French in Louisiana, well marked by concerted efforts to promote French culture, is likewise an inverse reflection of the integration process.

The socioeconomic history of settlements in the New World suggests that integration within the economically or politically dominant group was a critical factor in the general disappearance of African languages and regionalized loss of European languages in the Americas. The plantation industry did not develop overnight and was generally preceded by small farming industry in which slaves were generally well integrated (although discriminated against) in homestead settlements. (Besides, the plantation industry never replaced the farming economy, although it often grew out of it.) Reasons of practicality led the Africans to speak the languages of their masters or the local colonial languages as their vernaculars. Their children acquired these local colonial languages as their native vernaculars. ${ }^{14}$

By the time segregation was instituted in the colonies, typically decades later than the institution of indenture and/or slavery on the large plantations, the creole, and, later, seasoned slaves became the agents of enculturation and of linguistic transmission. Despite the gradual basilectalization among some of them, every new installment of slaves brought from different parts of Africa aimed at speaking the local vernacular as they heard it spoken by the creole and seasoned slaves. Its appropriation as their primary means of communication also led to the attrition of the African languages in the New World, while these in turn influenced the second language acquisition process and the development of new language varieties. The explanation for the loss of African languages lies thus in a simple effort on the part of African

14 This is a development observable even today in African urban centers, where the majority of children express more interest, or find it more practical, to speak only the city's lingua franca, which becomes their native vernacular. This is part of the trend that endangers some indigenous languages in Africa. 
captives to survive in the new ecology by being practical and acquiring the vernacular that would enable them to function in it.

Colonial history also suggests that Native American languages must have been endangered in two ways and at different periods. In the earlier stages of colonization, Native Americans were driven away and not integrated in the colonial populations, despite trade and negotiations of all kinds with them. The Native American languages were endangered then mostly by the decreasing numbers of their speakers, due to wars with the immigrants, to diseases brought over from the Old World (Crosby 1992), and to their relocations (Patricia C. Nichols 1993). This trend actually continues to date in Latin America, where the physical ecology qua habitat of Native Americans who have remained marginal to the everchanging world around them is being destroyed by modern industry (as evidenced by, for instance, the literature on deforestation). In all this history, we are reminded of the parasitic/symbiotic nature of language, whose fate depends very much on that of its hosts.

The second kind of endangerment is more recent in North America, concurrent with the absorption of Native Americans into the larger American populations that have already adopted English or French as their vernaculars or lingua francas, and with increased pressure on them since the late nineteenth century to shift to the same European languages in order to compete with the mainstream populations for jobs and feel integrated in them. Reservations in North America have lacked the socioeconomic vitality necessary to sustain their communities as autonomous and to keep them free from the lure of life in mainstream North American society or the pressures to acquire English or French.

Overall, general integration of populations of diverse backgrounds at the expense of Native American traditional ways of life, typically to the benefit of a capitalist socioeconomic system that originated in Europe, has entailed the erosion of the socioeconomic ecologies that supported Native American cultures. Hence, it has entailed the endangerment of $\mathrm{Na}$ tive American languages. No human intervention will stop the trend unless it recreates socioeconomic ecologies that may either grant them selective advantage or make them equally competitive with the European languages. A favorable ecology involves more than pride in one's cultural heritage. It involves more fundamentally the use that a speaker can make of such heritage to survive and thrive in the new way of life.

In Latin America, where the integration of Native Americans started earlier, as reflected by what may be identified as the Hispanicization of races, the one-sided restructuring of socioeconomic systems has favored the European cultures and languages. The only chance for the indigenous 
languages to survive and possibly thrive has lain in those Native Americans who did not participate in the physical hybridization of the people which was concurrent with the cultural assimilation of non-Europeans. Thus from the beginning of colonization, the Native American languages suffered from a numerical erosion of speakers, which was in inverse proportion to the people who shifted to Spanish or Portuguese, chose to acquire them as native languages, and showed little interest in their ancestral languages. 15

A species-internal interpretation of ecology. This section presupposes that languages are complex adaptive systems (CAS). They share with CASs in population genetics the following properties articulated by Brown (1995:14):

1. They consist of numerous components of many different kinds which interface with each other-some linguists will argue that such systems are modular.

2. The components interact nonlinearly and on different temporal and spatial scales-thus, the phonological component, for instance, may undergo some changes while the syntactic component barely does, or the semantic component may be more extensively influenced by another language than the syntactic component is.

3. They organize themselves to produce complex structures and behaviors-this is precisely the case even if one considered only, from a simple mechanical perspective, the complexities of the phonological, morphological, and syntactic subsystems and tried to explain how they interface to produce speech.

4. Some inherent features of the smaller units allow the systems to respond adaptively to environmental change- this captures the traditional concern of historical linguistics, which should also include the development of new varieties such as creoles.

5. Because the direction and magnitude of change is affected by preexisting conditions, there is always a legacy of history in the current system-this is what Mufwene (1996a) attempts to capture by the Founder Principle. For instance, American varieties of English reflect to a large extent the kinds of language varieties that the earliest colonists spoke, including nautical and non-English influence in the original proletarian colonial communities. (Dillard 1985, 1995)

\footnotetext{
15 Part of the attrition process followed from the intervention of European colonists in promoting some Native American languages, such as Quechua, as lingua francas (Calvet 1987). Mühlhäusler (1996) discusses consequences of similar European interventions in Melanesia.
} 
From a structural point of view, language evolution is marked by restructuring qua system reorganization (Mufwene 1996a). This may consist of the redistribution of phonemic contrasts in a language if some phonemes are lost, such as $/ æ, \partial, \wedge, \theta, \partial /$ in several new varieties of English, or when a new sound is introduced, such as the flap (the word-medial [D] in writer and rider) in American English. It may consist of new ways of introducing subordinate clauses, such as with the use of $s \mathcal{\varepsilon}<$ say, instead of that, to introduce object clauses but not relative clauses in Atlantic English creoles. The change may also consist in differing ways of weighting alternative markers of the same grammatical function, for instance, whether or not going to/gonna/gon/ga (pronounced [gə] in Gullah), or will functions as the primary marker of future in a particular English variety.

When several such changes co-occur, a language may be restructured into a new variety that some speakers may doubt belongs in their language. This has typically been the case for creoles, which linguists like to disfranchise as separate languages, against the sentiments of most of their speakers. Mufwene (1996b, 1997b, 1998) argues that basically the same restructuring formula takes place in all cases of language evolution which result in new varieties; the main difference lies in the specific distinctions and principles that have been affected, in the overall extent of restructuring, and in the sources of influences that affected the restructuring. I argue here that part of the ecology that determines such system reorganization lies within the affected language itself. Below, like in the previous section, I will invoke some specific examples of new varieties that developed by restructuring, which reflect an important role of language-internal ecology.

It appears from Trudgill (1986) that even without the presence of Africans and continental Europeans in the New World, North American varieties of English would have wound up different from British varieties of English. Important indirect evidence validating his observation comes from the fact that Australian, New Zealand, and Falkland Islands Englishes all sound different, reflecting in part differences in the specific compositions of the pools of features that competed with each other in these colonies. Even if the same features were taken to all these territories, their preference strengths relative to their competitors sometimes varied from one pool to another, which led to the selection and/or dominance of different variants from one new variety to another.

It so happens also that English in England and the United Kingdom was undergoing changes during the colonization of the Americas, Africa, and Asia by western European nations. Assuming incorrectly that English was originally homogeneous in England, differences in the timing of migrations 
to different colonies would also have produced differences, for instance, between Australian and American Englishes. They would simply reflect the variation in the varieties that were taken to the colonies, regardless of influence from the other languages that English came in contact with. The fact that Australia was colonized over 150 years later than North America is significant and must be considered as one of the species- internal ecological factors that bore on the evolution of English in these territories. Theoretically, different British varieties and pools of features were exported to Australia than to North America, although the latter also received these later varieties as adstrate influence on the new vernaculars that were already evolving.

However, English has always been regionally and socially diverse in England, and different mixes in the colonies would also yield different outputs to restructuring. This is precisely part of what seems to have happened as we correlate the regional English origins of settlers in parts of North America with the relevant regional dialects. According to Bailyn (1986) and Fischer (1989), settlement patterns in the original North American English colonies were not identical. Most of the colonists in New England, for instance, were Puritan farmers who migrated in family units from East Anglia. They engaged in family-run subsistence farms that used limited indentured or slave labor. They continued to interact among themselves in much the same way as they did in the metropole. Despite influence from speakers of other languages (e.g., French) and dialects (e.g. maritime English) that they came in contact with, New England's English is said to have remained the closest to British English. This is a situation where English's internal ecology in the colony varied little from that in the metropole, which prevented the language from being restructured as extensively as it did in other colonies or too differently from the evolutionary path of English in England.

On the other hand, the Chesapeake colonies (Virginia and Maryland in particular) were settled from more diverse places and socioeconomic classes in the British Isles. There were the plantocrats, who descended largely from British aristocratic families and came in family units and mostly from southern England cities, notably the London area (Fischer 1989). A large proportion of the colonists-up to seventy-five percent by the mid-seventeenth century according to some estimates (Kulikoff 1986, Fischer 1989) — came mostly as singles not only from southern England (London, Bristol, and Liverpool) but also from northern England, and many others from Ireland and Scotland. Most of those who came from Ireland did not speak English natively either, as English in Ireland was used pretty much the way it is used today in former British exploitation 
colonies of Africa and Asia. That is, it was spoken by the educated and/or those who had to interact closely with the colonizers.

Such internal diversity among the English-speaking colonists set things up for restructuring. Several variants came to compete with each other in novel ways and the selections that were made were not always consistent with those made in metropolitan cities-those important contact settings where, as noted above, English was also being restructured as a consequence of the same population movements that extended to the colonies. Nor were the selections identical with those made in New England, where the population mix was relatively conservative, with a majority of founder colonists who spoke alike already.

The Appalachian Mountains received larger proportions of Scots-Irish, who also came in family units and brought with them some Gaelic influence. Their English has been claimed to share features with Irish English, which also developed concurrently with English in North America, as the Irish have gradually shifted to English as their vernacular only since the seventeenth century. (Before then, as observed by Lüdtke in 1995, English was typically an urban and elite second language variety.) All these facts show that variation in the internal ecology of the colonial language bore significantly on how it would be restructured during its adaptation to its new external ecology.

Another species-external interpretation of ecology: A structural perspective. Part of the external ecology of English in North America consisted of the other languages that it came in contact with. As it was being appropriated as a vernacular by adult speakers among Africans and continental Europeans, the latter's languages often availed their structures as alternatives to those of the target, especially when there was partial structural or functional similarity between the relevant languages. This seems to have been the case with the introduction of object clause with say or in omitting the copula before a nonverbal predicate, as it may not have been identified as significant where it is contracted, as in he's shy/gone. ${ }^{16}$ In the case of say, the fact that it is often used in colloquial English to report speech quotatively is an important factor (Mufwene 1996c). Languages previously spoken by such new speakers of English influenced the restructuring that was independently in process with the change of its species-internal ecology, as explained above. In communities where the second-language speakers were either the majority or marginalized from the native speaking populations, knowledge of the

16 The fact that it is semantically empty lexically, although it carries tense in finite clauses, may have been a more significant factor, as several languages around the world do without a copula in similar constructions. 
other languages favored variants that were more consistent with their structures, causing some subsystems to evolve in directions that diverge from those of dialects that developed where either the native speakers were the majority or where the nonnative speakers were well integrated.

Focusing on the case of complementation with say, note that although colloquial and nonstandard English offers the alternative of quotative object clauses introduced by the verb say, its use as a subordinator in African-American English and Atlantic English creoles is much more extensive. In the latter variety it is used also for indirect reported speech and in combination with verbs other than verba dicendi, for instance, in Uh hear say Robert gone 'I heard that Robert is gone/has left' in Gullah. In African-American English, say also functions as a discourse marker used by the narrator to remind the listener that the speaker is still the same in a chunk of quotatively reported speech (Mufwene 1996c). ${ }^{17}$

The ethnographic ecology, as discussed above, definitely affected the role of the external structural ecology toward more, or less, influence, because it determined the particular conditions under which it was possible for a language to influence the restructuring of the target language. More examples will help articulate how all this works. The point here is to explain that when English came in contact with other languages, no particular restructuring process took place that was different in kind from what took place in situations in which mostly dialects of English came in contact with each other. In the vast majority of cases, English as a vernacular among descendants of Africans was restructured along parametric options that were available in the lexifier but were not equally weighted.

For instance, English has more than one kind of possessive construction, as in the cover of the book versus the book cover versus the book's cover. There is a semantic difference between the last two alternatives, but this may not have been so obvious to some nonnative speakers in colonial settings. Since several West African languages mark possession by word order only, on the pattern of book cover, it is not surprising that this pattern is so commonly the dominant one among Atlantic English creoles. In African-American English, it alternates freely with the Saxon genitive, as in the book's cover. The fact that in the relevant substrate languages the same possessive construction applies both to nominal and to pronominal possessor nouns accounts for constructions such as me/we book 'my/our

${ }^{17}$ On the other hand, recall that although in some contexts it can be interpreted as a substitute for that, it cannot be used to introduce a clause in complex noun phrases. This should make more explicit what is meant by the definition of restructuring as system reorganization. Not only are there new morphemes that replace, or alternate with, older ones, but also the functions of the new ones may not be identical with those of their alternates. 
book' in several of these creoles. (Incidentally, there are nonstandard dialects of English in which me book is normal.)

The above example suggests that at least in most cases, the respects in which English creoles differ structurally from other English varieties today are developments from English itself where the external structural ecology favored options not selected by the others. In several cases, these options were, of course, generalized to some novel uses, a process not so unusual in language change. Parallels to such developments may be observed in Atlantic French creoles, formed by Africans from more or less the same ethnographic backgrounds. French has the following possessive construction: NP de/à $\mathrm{NP}_{\text {poss }}$ and Pro ${ }_{\text {poss }}+\mathrm{NP}$, as in le livre de/à Jean/moi 'John's/my book' (literally, 'the book of/for John/me') and mon livre 'my book'. Haitian Creole selected only the option the closest to the first, applying it universally to nouns and pronouns alike, as in liv Jean/mwen, under the partial influence of the same African languages in which possession is indicated only by word order, regardless of whether the possessor is nominal or pronominal. In French, only tonic pronouns are used as nouns, as in le livre à moi. Otherwise, a possessive pronoun, preceding the possessive noun phrase, is used, as in mon livre. (Interestingly, Haitian Creole pronouns developed from French tonic pronouns.)

Mufwene (1996a, 1998) discusses more such examples, which will not be repeated here, regarding serial predicate constructions, negation, individuation, and the role of the stative/nonstative distinction. They show that generally creoles have restructured options available in the lexifier according to patterns consistent with some of the languages that they came in contact with. There is evidence of such external ecological structural influence in the development of noncreole varieties of English in North America, too. One such influence is the bring/take/come/go with construction, as in Mary bought a card to bring/take with, which seems to have developed under German influence (Goodman 1993). Another comes from Trudgill's (1986) discussion of the alternation between infinitival and gerund object clauses in English, as in (It was) nice to see/seeing you. Trudgill observes that the infinitival construction is used more commonly in North America than in the United Kingdom. According to him, this change in the preference of the two alternants may reflect influence of continental European languages that came in contact with English in colonial North America: most of them do not have a gerund and use an infinitival construction in similar syntactic environments. The explanation is consistent with the fact that, since the founding of the North American colonies, part of the European colonists came from continental Europe. 
These examples illustrate what has been evident all along in the literature on second language acquisition: The speech of nonnative speakers is typically influenced by features of their own native languages. More accurately, it is influenced by languages they have been speaking prior to the latest. ${ }^{18}$ Let us identify such languages for convenience as substrates. What we are learning is that once such speakers are either marginalized by segregation or form a significant proportion of a new community, they are very likely to influence the restructuring of the new language they have appropriated as their vernacular, either by selecting options consistent with some of the substrate systems or by introducing in it features that it just did not have. Segregation and integration are matters of degree. Basically, the same explanation applies to the developments of ethnic varieties such as Jewish and Italian Englishes among European Americans.

In the competition-and-selection approach proposed in Mufwene (1996a), the language that prevails actually wins a pyrrhic victory, as it adapts itself to its new speakers, i.e., part of its changing ecology. This validates again approaching language as a parasitic/symbiotic species and seeing its evolution in terms of how it adapts itself to the responses of its new hosts while affecting, or eliminating, other linguistic symbionts that it comes in contact with. How natural selection, which operates at the basic level of individual speakers, spreads at the level of the society is, of course, part of what linguistics is expected to explain, taking into account processes such as accommodation, which leads to focusing in Le Page and Tabouret-Keller's (1985) sense, and ethnographic notions such as communication networks.

The strong version of my approach to language evolution is that the competition-and-selection process has been typical of language change in any community and at any time. Languages are generally osmotic and the traditional distinction between language-internal and language-external causes of change seems irrelevant. The main cause lies in the punctuation of equilibrium which affects the extant system. ${ }^{19}$ Regarding restructuring, there seems to be no obvious processual difference in whether the features which compete with each other are inherent in the same language

18 More and more creolists agree that creoles and the like have resulted from the restructuring of the lexifier not by children but by adult speakers. This explanation is also consistent with the socioeconomic histories of the territories where the new language varieties have developed (Mufwene 1996a).

19 Also inspired by evolutionary biology, especially by the views of Steven Jay Gould (1993), Dixon (1997:73-84, 139-41) invokes punctuated equilibrium to account for language change, arguing that significant changes happen in shorter periods of time than historical linguistics has led us to believe. This suggests, contrary to his own position, that creoles are normal instances of punctuation of the equilibrium in a particular language qua species in a new ecology. 
variety or in more than one, and whether the varieties in contact and in competition are assumed to be the same language or separate ones (Mufwene 1998).

\section{In conclusion, how history repeats itself}

The history of English in North America is largely reminiscent of what happened over one thousand years ago in England, and much of the same explanation proposed above applies to language evolution in different parts of the world. In the early Middle Ages, the Angles, Jutes, and Saxons, who spoke related Germanic language varieties but perhaps not the same language, migrated to England; their descendants have ruled it ever since. First they drove away or killed some of the indigenous Celts. Eventually, they assimilated the survivors through a government system that led to the attrition or extinction of the Celtic languages, of which Welsh and Gaelic are apparently the best known cases.

Up to the seventeenth century, very few Irish-typically in urban centers-appropriated English as a vernacular. It remained a foreign language. Although the integration process started earlier in Wales, the development of Old English, then confined as a vernacular to England, must be interpreted largely on account of contacts among the invaders/settlers themselves, as they accommodated each other. Explanations of subsequent changes all the way to Early Modern English must, however, factor in contacts of English with Old Norse, Latin, and Norman French. Explanations of why these languages died in England, or why they did not lead English to extinction but only influenced its structures, must be sought in English's external ecology, especially in the ethnographic symbiosis that obtained between it and these other languages. ${ }^{20}$ On the other hand, English's internal ecology should explain why the influence of French is more significant in its educated varieties than in its nonstandard vernaculars.

The fact that English endangered the Celtic languages is actually quite informative, as we learn from its ethnographic history that political

\footnotetext{
20The deaths of Old Norse and Norman French in England illustrate again those situations in which part of a species is disfavored by one particular ecology, while the remainder is well sustained by another. Old Norse developed into Norwegian and Danish, and continental varieties of medieval French have developed into today's varieties of French in and outside France. Power may not be an important component of the explanation, because Old Norse and Norman French were associated with the powerful in England, unlike the African languages that died in the Americas and the Indian Ocean. Integration into the demographically dominant population in the case of England may be a more plausible explanation.
} 
power is not as critical an explanation as it looks regarding language endangerment. These languages survived as long as their speakers were not assimilated to the Germanic rulers, just like the Native Americans who were not killed in the colonial invasion were able to preserve several of their languages up to the early twentieth century, and Africans and Asians in their homelands have preserved their indigenous languages. ${ }^{21}$ In both cases, the indigenous populations were marginalized and continued to interact mostly among themselves and in their own languages. Gradual socioeconomic integration since the seventeenth century led the Irish to interact more and more and in less subservient terms with the rulers. In the process, more and more of them have shifted to English, just like the gradual socioeconomic demarginalization of Native Americans has been a catalyst in the endangerment of the indigenous languages. There are, of course, differences in the ecological structures of these integration processes, but we need not get into them here.

Irish and Scottish Englishes have developed from the appropriation of English by the Celts, more or less like indigenized varieties of English in Africa and Asia (see below and Mufwene 1997b), whereas Native American varieties of English (Mithun 1992) do not seem to have developed to the same extent, at least not in the same way or with the same vitality as, say, African-American English in the United States or English creoles in the Caribbean. The ecologies of the integration process have of course not been identical for the Africans and Native Americans. For instance, while marginalized and yet integrated to some extent (until the Jim Crow laws were passed in the late nineteenth century), the Africans in English North American colonies needed English to communicate among themselves; hence their usage of it as a vernacular among themselves, in gradually segregated communities, made more allowance for distinctive patterns of their own to develop. ${ }^{22}$ Similar developments have taken place among immigrants who aggregated in communities of their own, more recently the Hispanic immigrants. On the other hand, at least during the colonial

21 There are of course several African languages that are endangered today, however, because they are being driven out of competition by other African languages, especially the lingua francas which are becoming urban vernaculars, but not by the European colonial languages. (See Mazrui and Mazrui 1998 on this subject.)

22 To elaborate the explanation provided above in $A$ species external interpretation of ecology: An ethnographic perspective, an important reason for this rapid language shift among the Africans in the New World is societal multilingualism, which impeded routine communication. Even if, on large plantations, handfuls of slaves may have come from the same areas in Africa and may have shared one or another lingua franca, there was nothing in the colonial political and economic ecologies that sustained the transmission of these languages from generation to generation. As noted above, the preservation of Yoruba in Trinidad was exceptional, under post-Abolition ecological conditions. 
period, the Native Americans needed English less to communicate among themselves than with the colonists and other immigrants. The endangerment of their languages in the twentieth century is largely the result of their relative integration into, or dependence on, the mainstream American socioeconomic ecology, which has eroded their language transmission from one generation to another. As with other ethnic groups, the restructuring of English among them has been inversely correlated to their relative integration in the dominant culture.

Integration accounts also inversely for why African-American English is still thriving as a distinct variety and may continue to do so for several generations to come: In the main, European and African-American communities form their own separate mega-networks of communication whose members do not have to accommodate each other but must learn the other network's variety if they want to participate in their social or economic activities. This trend has typically been in the direction of white middle-class varieties of English, with African Americans having to learn (white) educated English. At the same time, they are also under pressure of ethnic loyalty to preserve African-American features within "the community". ${ }^{23}$

I should clarify that no ecological factor alone accounts for everything. Lack of, or less, integration does not explain why African-American vernacular English is closer to white nonstandard varieties of English in North America than Gullah; its creole kin is. Gullah developed in colonial settings where the Africans were the majority, in the rice fields of coastal South Carolina and Georgia, in settings similar to the sugar cane plantations of the Caribbean, where similar English creoles have also developed. Rigid segregation was instituted within fifty years of the founding of South Carolina, thus enabling early divergence of African-American and European-American speech habits. On the other hand, African-American vernacular English developed on the tobacco and cotton plantations of the hinterlands, as well as on smaller farms, where the Africans were the minority. Although there has always been discrimination against them, they were not rigidly segregated until the last quarter of the nineteenth century, after the Jim Crow laws were passed. Although this fostered the divergence of African-American and European-American vernaculars, the preceding 250 years of common socioeconomic history, marked by regular interactions between the two groups, account for the large amount of

${ }^{23}$ This dual pressure may not be an African-American peculiarity. Note, for instance, that American white southern English is stigmatized but is far from being endangered in the southern states, despite equal pressure on white southerners to use the same educated English taught in the school system. 
similarities among them, which are due to more than sharing the lexifier (see also Mufwene, in press).

We should note in the development of African-American varieties of English a phenomenon that is inversely reminiscent of the appropriation of English by the Celts in the British Isles and Native Americans. At first, the latter populations were marginalized by the English. Subsequent, gradual integration led them to shift to English and develop new varieties. The Africans were integrated early but marginalized after appropriating the language. In the case of Gullah, its greater divergence is due largely to later massive importations of servile labor under conditions of rapid population replacement in which fewer and fewer native speakers of the colonial English varieties among the slaves served as models (Mufwene 1996a). These conditions favored the basilectalization of the vernacular, i.e., its restructuring further away from the lexifier.

The indigenized varieties of English spoken by Native Americans could not thrive as long as their speakers were being absorbed by the general American populations outside the reservations. Irish and Scottish English thrive because they are spoken in their homelands, in which the speakers are the majority and use it to communicate among themselves. ${ }^{24}$

Getting back to the development of European-American varieties of English, the process also has more concomitants in the United Kingdom itself. According to Bailyn (1986), British emigrations to extra-European colonies in the seventeenth and eighteenth centuries were an extension of population movements that were taking place in the British Isles. People in search of jobs moved to different parts of the British Isles, which led to the restructuring of English, especially in urban centers such as London, Liverpool, and Bristol, to which northern populations migrated and from which a large proportion of the colonists also emigrated.

The fact that population movements in England in the seventeenth and eighteenth centuries caused English to restructure into diverse contemporary dialects is evidence that English in North America and in other former settlement colonies would have changed even if it did not come into contact with other languages. That more than one particular dialect emerged in England since then, some of them probably more conservative than others, is also evidence that extra-European varieties of English would still be different from British varieties, because neither the actual English variants in contact and competing with each other nor their strengths were identical from one contact setting to another. More recent evidence for my position may be found in the development of recent

${ }^{24}$ Although Native Americans are in their homelands, the socioeconomic ecology has changed to where external pressures seem to have disempowered them linguistically. 
British dialects out of recent population movements such as reported by Kerswill and Williams (1994) and Britain (1997).

Overall, answers to diverse questions about language evolution, such as why a particular language was restructured and in which specific ways, or why a particular language was/is endangered, are to be found in its ecology, both internal and external, and both structural and nonstructural. Such considerations undermine the significance of the distinction between internally motivated and externally motivated linguistic change, except for sociological reasons. Linguistic systems seem to be rather osmotic; and no differences in kind of structural processes may be clearly associated exclusively with external or internal ecological factors. Approaching language as species makes it possible to capitalize on variation within a population, to highlight factors that govern the competition and selection processes when equilibrium is punctuated in a speech community, to pay particular attention to the linguistic behaviors of individual speakers, on whom selection operates, and thereby to understand language evolution better as we can make more explanatory uses of notions such as accommodation, networks of communication, and focusing.

\section{References}

Bailey, Guy, and Erik Thomas. 1998. Some aspects of African-American vernacular English phonology. In Salikoko S. Mufwene and John R. Rickford, et al. (eds.), African-American English: Structure, history, and use, 85-109. London: Routledge.

Bailyn, Bernard. 1986. The peopling of British North America: An introduction. New York: Random House.

Britain, David. 1997. Dialect contact and phonological reallocation: Canadian raising in the English fens. Language in Society 26:15-46.

Brown, James H. 1995. Macroecology. Chicago, Ill.: University of Chicago Press.

Calvet, Louis-Jean. 1987. La guerre des langues et politiques linguistiques. Paris: Payot.

Crosby, Alfred W. 1992. Ills. In Alan L. Karras and John Robert McNeill (eds.), Atlantic American societies: From Columbus through abolition 1492-1888, 19-39. London: Routledge.

Dillard, Joey Lee 1985. Toward a social history of American English. Berlin: Mouton.

- 1995. American English in the English diaspora. In Zoltán Kövecses (ed.), New approaches to American English, 3-18. Budapest: Department of American Studies, Eötvös Loránd University. 
Dixon, Robert M. W. 1997. The rise and fall of languages. Cambridge: Cambridge University Press.

Fischer, David Hackett. 1989. Albion's seed: Four British folkways in America. Oxford: Oxford University Press.

Friedman, Victor A. 1996. Observing the observers: Language, ethnicity, and power in the 1994 Macedonian census and beyond. In Barnett R. Rubin (ed.), Toward comprehensive peace in Southeast Europe: Conflict prevention in the South Balkans, 81-105. New York: The Twentieth Century Fund Press.

Giles, Howard, and Philip Smith. 1979. Accommodation theory: Optimal levels of convergence. In Howard Giles and Robert St Clair (eds.), Language and social psychology, 45-65. Oxford: Basil Blackwell.

Goodman, Morris. 1993. African substratum: Some cautionary words. In Salikoko S. Mufwene (ed.), Africanisms in Afro-American language varieties, 64-73. Athens, Ga.: University of Georgia Press.

Gould, Steven Jay. 1993. Eight little piggies: Reflections in natural history. New York: W. W. Norton and Co.

Hagège, Claude. 1993. The language builder: An essay on the human signature in linguistic morphogenesis. Amsterdam: John Benjamins. Haugen, Einar. 1971. The ecology of language. The Linguistic Reporter 13, Supplement 25:19-25. Also in Anwar S. Dil (ed.), 1972, The ecology of language: Essays by Einar Haugen, 324-39. Stanford, Calif.: Stanford University Press.

Hoeningswald, Henry M. 1989. Language obsolescence and language history: Matters of linearity, leveling, loss, and the like. In Nancy C. Dorian (ed.), Investigating obsolescence: Studies in language contraction and death, 347-54. Cambridge: Cambridge University Press.

Keller, Rudi. 1994. On language change: The invisible hand in language. London: Routledge.

Kerswill, Paul, and Ann Williams. 1994. A new dialect in a new city: Children's and adults' speech in Milton Keynes. Final Report on a project funded by the Economic and Social Research Council.

Kouwenberg, SILvia. 1994. A grammar of Berbice Dutch Creole. Berlin: Mouton De Greuter.

Kulikoff, Allan. 1986. Tobacco and slaves: The development of southern cultures in the Chesapeake, 1680-1800. Chapel Hill, N.C.: University of North Carolina Press.

Labov, William. 1994. Principles of language change: Internal factors. Oxford: Basil Blackwell. 
1998. Co-existent systems in African-American vernacular English. In Salikoko S. Mufwene and John R. Rickford et al. (eds.), African-American English: Structure, history, and use, 110-53. London: Routledge.

Le Page, R. B., and Andrée Tabouret-Keller. 1985. Acts of identity: Creolebased approaches to language and identity. Cambridge: Cambridge University Press.

Lüdtke, Helmut. 1995. On the origin of Modern and Middle English. In Jacek Fisiak (ed.), Linguistic change under contact conditions, 51-53. Berlin: Mouton de Gruyter.

Manheim, Bruce. 1991. The language of the Inka since the European invasion. Austin: University of Texas Press.

Mazrui, Ali, and Alamin Mazrui. 1998. The power of Babel: Language in the African experience. Oxford: James Currey/Chicago: University of Chicago Press.

Milroy, James. 1992. Linguistic variation and change: On the historical sociolinguistics of English. Oxford: Blackwell.

_ speaker innovation. Journal of Linguistics 21:339-84.

Mithun, Marianne. 1992. The substratum in grammar and discourse. In Ernst Håkon Jahr (ed.), Language contact: Theoretical and empirical studies, 103-15. Berlin: Mouton de Gruyter.

Mufwene, Salikoko S. 1996a. The founder principle in creole genesis. Diachronica 13:83-134.

1996b. The development of American Englishes: Some questions from a creole genesis perspective. In Edgar Schneider (ed.), Varieties of English around the world: Focus on the USA, 231-64. Amsterdam: John Benjamins.

- 1996c. Creolization and grammaticization: What creolistics could contribute to research on grammaticization. In Philip Baker and Anand Syea (eds.), Changing meanings, changing functions, 5-28. Westminster: University of Westminster Press.

- 1997a. Métissages des peuples et métissages des langues. In Marie-Christine Hazaël-Massieux and Didier de Robillard (eds.), Contacts de langues, contacts de cultures, créolisation, 51-70. Paris: L'Harmattan.

1997b. The legitimate and illegitimate offspring of English. In Larry Smith and Michael L. Forman (eds.), World Englishes 2000, 182-203. Honolulu, Hawaii: College of Languages, Linguistics and Literature, University of Hawaii and the East-West Center. 
1998. What research on creole genesis can contribute to historical linguistics. In Dieter Stein and Monika Schmidt (eds.), Proceedings of the XIII International Conference on Historical Linguistics, 315-38. Amsterdam: John Benjamins.

- in press. Accountability in descriptions of creoles. In John R. Rickford and Suzanne Romaine (eds.), Creole genesis, attitudes, and discourse: Studies celebrating Charlene J. Sato. Amsterdam: John Benjamins.

Mühlhäusler, Peter. 1996. Linguistic ecology: Language change and linguistic imperialism in the Pacific region. London: Routledge.

Nichols, Johanna. 1994. Linguistic diversity in space and time: Chicago, Ill.: University of Chicago Press.

Nichols, Patricia C. 1993. Language contact and shift in early South Carolina. Paper presented at the annual meeting of the Linguistic Society of America, Los Angeles, California.

O'Hara, Robert J. 1994. Evolutionary history and the species problem. American Zoology 34:12-22.

Robinson, Clinton D. W. 1997. Developing or destroying languages: What does intervention do to linguistic vitality? Notes on Sociolinguistics 2(3):109-26.

Smith, Norval. 1995. An annotated list of pidgins, creoles, and mixed languages. In Jacques Arends, Pieter Muysken, and Norval Smith (eds.), Pidgins and Creoles: An introduction, 331-74. Amsterdam: John Benjamins.

Thompson, John N. 1994. The coevolutionary process. Chicago, Ill.: University of Chicago Press.

Trudgill, Peter. 1986. Dialects in contact. New York: Basil Blackwell. Voegelin, Charles F., Florence M. Voegelin, and Noel W. Schutz, Jr. 1967. The language situation in Arizona as part of the Southwest culture area. In Dell Hymes and William E. Bittle (eds.), Studies in Southwestern ethnolinguistics: Meaning and history in the languages of the American Southwest, 403-51. The Hague: Mouton.

Warner-Lewis, Maureen. 1996. Trinidad Yoruba: From mother tongue to memory. Tuscaloosa: University of Alabama Press.

Weinreich, Uriel. 1953. Languages in contact: Findings and problems. New York: Linguistic Circle of New York. 
